\title{
EVALUATION OF SELECTED NURSERY TRAITS IN COMBINATION ROOTSTOCKS AND VARIETY IN ASIAN PEAR TREES
}

\author{
T. Nečas, K. Lébl
}

Recieved: Semptember 13, 2012

\begin{abstract}
NEČAS, T., LÉBL, K.: Evaluation of selected nursery traits in combination rootstocks and variety for Asian pear trees. Acta univ. agric. et silvic. Mendel. Brun., 2012, LX, No. 8, pp. 171-180

Evaluation of the nursery traits of rootstocks and varieties is an important tool for optimisation of the fruit orchard plants final growing. The present experiment evaluated the standard and progressive rootstocks for the pear trees in combination with the Asian varieties of P. pyrifolia Nakai. a P. ussuriensis Maxim. in comparison with the control variety 'Conference' P. communis $\mathrm{L}$. The evaluation was focused on such properties as affinity, growth of the tree propagated by budding, thickness of the root crown at the rootstock and the root suckering. Their interactions were tested statistically. The highest values of affinity within the nursery were achieved with the following rootstocks: 'BET' (96.6\%), 'FOX 11' (95.5\%), and 'MA' (94.4\%). 'Hosui' was identified as the variety with the greatest growing capacity, with an average gain of $1238.2 \mathrm{~mm}$. The most supported variety growth was exhibited by the 'FOX 11 ' rootstock, with an average gain of the trees propagated by budding of $1388.8 \mathrm{~mm}$. The growth intensity itself was demonstrated most in the thickness of the root crown of the 'BET' (P. betulifolia) rootstock, namely $15.8 \mathrm{~mm}$. The rootstock that exhibited the strongest root suckering was also 'BET' with 6.2 suckers per rootstock. The identified differences between the varieties and rootstocks were confirmed as statistically significant or even highly statistically significant.
\end{abstract}

Nashi, quince, pomes fruit, chip budding, budded plant, affinity

Asian pear trees come from the Eastern and North-Eastern Asia, unlike the European ones which come from the Caucasus Mountains. They are grown mostly in China, Japan, and Korea and to a lesser extent in other Asian countries as well. It is rare to find extensive orchards in Europe. Other major producers are India, New Zealand, Australia, USA and some Southern American countries (FAO, 2010). Production of Asian pears sees rapid development, especially in China. China produces more Asian pears than any other country in the world. Compared with the annual production of approx. 15 million tonnes, i.e. 67\% of the world production, the European varieties only account for $2 \%$ thereof; the rest features the Asian varieties with farming area of more than 1 million hectares (68\% of the world area for pear growing), (FAO, 2010). With these figures, pears are the most largely produced fruit in China second only to apples
(Jun, Hongsheng, 2002; FAO, 2010). In the last 5 years, pear growing in Asia has increased by $22.8 \%$ to exceed 17.2 million tonnes. This means the production has doubled since 1995 (Gemma, 2008). Fruit production in the Czech Republic reaches nearly 298,000 tonnes (2010, which is a decrease by $29 \%$ against 2009), with the intensive production orchards accounting for $41 \%$ of this production (121,000 tonnes), whereas the extensive orchards (predominantly minor farmers and producers) accounts for 59\% (176,000 tonnes). Proportion of pear production in the entire fruit production has reached critical value of $5.6 \%$, whereas apples represent $67 \%$ (as of 2010). Total pear production in 2010 equalled 16,100 tonnes. Average yield was 8.33 t.ha $^{-1}$. Average yield per 1 hectare of intensive orchards from 1984 to 2010 was approx. 9.4 tonnes (Buchtová, 2011). 


\section{Major reasons for stagnation of pear tree orchards include:}

- lack of pear tree weak-growing rootstocks (at the M9 level in apple) suitable for intensive orchards - vegetatively propagated rootstocks;

- insufficient growers' awareness of varieties resistant to Erwinia (interspecific hybrids, Asian varieties);

- unresolved issues concerning the inhibition of pear psylla invasion (Cacopsylla pyricola Foerster. and Cacopsylla pyri (L.) and the associated elimination of occurrence of pear decline - "PD" caused by phytoplasma);

Major species involved in the generation of cultural varieties of Asian origin: P. pyrifolia (syn. P. serotina) grown mostly in Japan. The predominating species in China are P. ussuriensis, P. bretschneideri and P. sinkiangensis. Such species as P. betulaefolia and P. calleryana are used primarily as rootstocks for growing (Luo, Zhang, 2002). 72\% of all known pear species are estimated to come from Asia. Some of them nowadays face total extinction, e.g. P. koehnei (Nee et al., 2002). At present (2012), there are two varieties of Asian pear trees registered in the Czech Republic, species Pyrus pyrifolia (Burm. f.) Nakai var. culta (Mak.) Nakai, namely 'Julka', summer variety (registered 2010, maintained by VŠÚO Holovousy, s.r.o.) and 'Rafzas', autumn variety (registered 2009, maintained by Promo-Fruit AG, Switzerland, represented in the Czech Republic by Ökoplant international, s. r. o.) (ÚKZÚZ, 2012).

In the world, the vegetatively propagated quince rootstocks are used primarily for their dense and fruitful orchards (Musacchi, 2006). Nevertheless, the quince rootstocks also have some negative traits that significantly restrict their use. One of the negative traits is their poor affinity with the main varieties, especially those of world-wide assortment (varieties 'Abate fetel', 'Williams', 'Bosc', etc.) as well as Asianorigin varieties. Quartieri et al. (2011), mentions several reasons for stagnating use of vegetatively propagated pear tree rootstocks. The major reason is their strong growth, delayed fertility, deteriorating quality of fruits (particularly shrinkage). In the Czech Republic, the situation is quite similar both in quince and in pear tree rootstocks. The majority of pear tree rootstocks propagated by seeds grow exuberantly and thereby disallow to establish orchards with intensive dense spacing (2000+ pieces per hectare) which is one of the reason for the orchard stagnation experienced in the Czech Republic (Nečas, 2011).

In the Czech Republic, within a common nursery practice, the pear tree rootstocks are only produced in a minimal quantity, and it is only the generatively propagated pear tree seedling. The quince rootstocks are represented by 5 rootstocks types with a total production of 82.288 pieces (which makes only $5.1 \%$ of the production of the vegetatively propagated apple tree rootstocks, (Nečas, 2011).
The experiment evaluated the nursery traits of the rootstocks and grafted variety of the perspective rootstocks and Asian varieties. The pear tree rootstocks such as 'Pyrodwarf', 'Pyroplus', 'OHxF 333', or the quince rootstocks such as 'MC', 'BA-29', and 'Cydomalus', allow achieving the similar values of orchard density and intensification as with those of apple trees on the ' $\mathrm{M}$ 9' rootstock or variety of rootstocks 'J-TE-G' and 'M 26'. The Asian varieties in the assortment, which includes varieties resistant to fire blight (Erwinia amylowora), pear psylla, European pear russetting and pear decline (Seemüller et al., 1998; Bell, 2003; Brewer et al., 2011; Bokszczanin et al., 2012; NCGR, 2012). The aim of the experiment was to select a suitable combination of rootstock/ variety, with optimum growth properties for growing the Asian pears in the Czech local conditions.

\section{MATERIALS AND METHODS}

The experiment was set up in the autumn of 2006 by transplanting the acquired rootstocks onto an experimental field. Evaluation was carried out over the years 2008-2010. The evaluation was focused on a total of 9 selected standard and perspective rootstocks:

1) vegetatively propagated pear tree rootstocks:

'Pyriam'- (supplied by Pépinières Lafond, Valreas, France). The rootstock was cross-bred in France (P. nivalis $\times$ P.heterofolia). It can be characterised as tolerant of or resistant to fire blight (Erwinia amylovora (Burrill) Winslow et al.), shows good affinity and does not branch in the nursery (Simard, et al., 2002). 'OHxF 333' (Brokmal) - (supplied by VŠÚO Holovousy s.r.o.). In terms of growth intensity, the rootstock is classified as moderately weak growing. It is reported to be resistant to fire blight (Erwinia amylovora (Burrill) Winslow et al.) and pear decline (Kviklys, 2008). 'Pyrodwarf"' - (supplied by Vivai Battistiny, Italy). This rootstock was selection from the cross-bred offspring of 'Old Home' $\mathrm{x}$ 'Bonne Louise d' Avranches'. The rootstock has good affinity with the grafted varieties, is frost-resistant, and exhibits weak root suckering and medium resistance to fire blight. It is easily propagable by means of hard and soft cuttings (Jacob, 1998). 'FOX 11" - (supplied by Vivai Battistiny, Italy). The rootstock was selected, as seedlings from pollination of the variety 'Volpina'. It is tolerant to Agrobacterium tumefaciens and susceptible to fire blight. Affinity with the majority of cultivars is excellent, suitable for medium dense orchards with 1500 trees/hectare (Quartieri et al., 2011).

2) vegetatively propagated quince rootstocks:

'quince S1' - (supplied by Fytos Plzeň). The rootstock was selected in Poland, and belongs to the Angers quince type. Its growth intensity is at the level of 'MA' quince. It is characterised by frost resistance though it terminates the vegetation quite slowly (Nečas, 2010). 'quince MA' - (supplied by Fytos Plzeň). It is a selection of Angers quince. It shows good affinity with the variety 'Conference', 
'Pastornice' ('Poire de Curé', 'Pastorenbirne'), 'Madame Verte', 'Beurre Hardy', 'Doyenné du Comice' and 'Beurre Diel'. It has poor affinity with the variety 'Clapp', 'Červencová', 'Bosc', 'President Drouard', 'Charneu', 'Beurre Alexandre Lucas', 'Williams', 'Abate fetel' (Marangoni, Rivalta,1995), (Vachůn, 2001). 'quince BA 29' - (supplied by Vivai Battistiny, Italy). As of recently, widely spread quince rootstock of French origin, selected from the Provence type of quince. Growth intensity is by $20 \%$ higher than the 'MA' rootstock. Varieties have higher affinity with this rootstock than with the 'MA' rootstock. In nursery, it provides a well-balanced growth of trees. In a stool bed it propagates more successfully than the 'MA' quince (Nečas, 2010).

3) generatively propagated pear tree rootstocks:

'BET' (Pyrus betulifolia) - (seeds supplied by Florsilva Ansaloni, San Lazzaro di Savena, Italy). Rootstock with great growing capacity, with partially unbalanced offspring. Thanks to its quite good compatibility with other Asian pear trees, it is used as the most frequent pear tree rootstock in Asia and the Americas (Mitcham, Elkins, 2007). It poorly propagates by means of hard and soft cuttings (Loreti, Morini, 1977). As a rootstock, it is highly tolerant to salinisation and higher contents of $\mathrm{CaCO}_{3}$ in the soil (Matsumoto et al., 2008). 'pear seedling' - (supplied by Fytos Plzeň). Generated from the seeds of cultivated varieties with highly developed seeds from variety 'Bosc'. Due to big fruits, the seed yield is quite low (Vachůn, 2001). Its affinity with all cultivars is very good. Its growth is exuberant, delaying the fertility onset, the fertility itself is good. Fruits are smaller in size than those on quince and less coloured (Marangoni, Rivalta,1995).

Scions for rootstock budding were selected and used to include varieties of the following species: Pyrus communis L., Pyrus pyrifolia NAKAI. and Pyrus ussuriensis MAXIM. The following varieties were budded in the summer of 2007:

- 'Conference' - representative of European pear trees and the control variety in the experiment (supplied by Sempra Litoměřice, Czech Republic).

- 'Ya Li' (Pyrus ussuriensis MAXIM.) - representative of Asian pear trees (Chinese group of varieties, collection assortments of the Faculty of Horticulture in Lednice).

- 'Hosui' (Pyrus pyrifolia NAKAI.) - representative of Asian pear trees (Japanese group of varieties, collection assortments of the Faculty of Horticulture in Lednice).

The experiment was carried out by 10 pieces and 2 repetitions, and 10 pieces of the rootstocks/ varieties combination. This makes a total of 30 pieces tested per combination. A total of 810 grafted trees were evaluated in the entire experiment. The budding procedure involved the T-shaped slit at a height of $150-200 \mathrm{~mm}$. The trees propagated by budding were given a standard nursery treatment, in early spring a sharp slit was made, in June the annual shoots were bound to the bamboo supports, in August the trunks and rootstocks were cleared of ambient growth. Evaluation in the nursery was carried out at monthly intervals, from the sharp slit to the final breeding of the tree crown (20082011), as a part of the experiment was additionally budded and re-budded over the years 2008-2009. The finished nursery cultivars were used over the years 2010-2011 for the orchard of another part of the experiment.

The decisive nursery characteristics were evaluated within the experiment, such as: affinity between the bud and the rootstock, root suckering, growth intensity, quality of branching. Evaluation of the aforesaid signs was carried out according to the "Methodology of state examination of varieties - fruit crops" (Kalášek et al., 1980). Statistika ver.10 program was used for statistical testing of the acquired data by the single- and two-factor analysis of variance.

\section{RESULTS AND DISCUSSION}

Major testing criteria for the suitable nursery traits of rootstocks include affinity of the rootstock with the varieties. In the experiment, the affinity was evaluated as a percentage of the well-taken buds of the total number of trees propagated by budding in the given combination rootstock/variety. The highest affinity of buds was achieved with the seed rootstock 'BET' - Pyrus betulifolia at a level close to one hundred per cent or $99.6 \%$ (Tab. I). High affinity was also achieved with the pear tree rootstock 'FOX 11', namely $95.5 \%$. The lowest affinity during the evaluation within the nursery was identified at the quince rootstock 'SI' (74.1\%). Relatively low values of affinity were exhibited by the 'Pyriam' rootstock. The reason for these low figures is not obvious as both Simard (2002) and Iglesias (2011a) report high affinity for 'Pyriam' (OHIl). These results rather imply some technical problem. Results that shall become a topic for discussion are those reached with the pear tree seedling, which only achieved an average affinity (84.4\%) Whereas Koběluš et al. (2007), in his evaluation of traits of the rootstocks in combination with the Czech varieties of pear trees, reports the achieved average affinity of 93.0\% with the pear tree seedling. However, similar results were obtained with the quince rootstock 'S1', which has also exhibited the poorest affinity (72.5\%). Fig. 1 shows the values of affinity achieved with the used varieties, where - owing to the nature of the rootstocks used - the highest capacity for well-taking has been exhibited by the variety 'Conference' (95.4\%) which has an acceptable affinity both with the pear tree rootstocks and the quince rootstocks. Comparison of affinity between the pear tree and the quince rootstocks identified minimum differences during the evaluation within the nursery. The pear tree rootstocks achieved an average affinity of $88.6 \%$, whereas the quince rootstocks $84.2 \%$. Fig. 2 shows the affinity values 
I: Average values of affinity achieved in rootstocks (2009)

\begin{tabular}{lc}
\hline \multicolumn{1}{c}{ Roots tocks } & Affinity in \% \\
\hline BET & 99.6 \\
FOX11 & 95.5 \\
MA & 94.4 \\
Pyrodwarf & 88.2 \\
pear seedling & 84.4 \\
BA29 & 84.2 \\
OHxF 333 & 82.2 \\
Pyriam & 81.9 \\
S1 & 74.1 \\
\hline
\end{tabular}

achieved in individual varieties, and the level of the overall affinity of the varieties.

Statistical analysis using the method of single-factor analysis of variance confirmed the statistically significant differences in the affinity between individual varieties (Fig. 3), or between the 'Conference' and the 'Hosui' varieties, which demonstrated the lowest affinity (79.9\%). No
II: Evaluation of the nursery traits, average data for the years 20082010

\begin{tabular}{lccc}
\hline Roots tocks & $\begin{array}{c}\text { Height of } \\
\text { trees [mm] }\end{array}$ & $\begin{array}{c}\text { Thick of root } \\
\text { crown [mm] }\end{array}$ & $\begin{array}{c}\text { Number of } \\
\text { suckers [pieces] }\end{array}$ \\
\hline FOX 11 & 1388.8 & 15.1 & 4.3 \\
pear seedling & 1288.8 & 14.8 & 5.6 \\
BET & 1171.3 & 15.8 & 6.2 \\
Pyriam & 1149.0 & 14.0 & 4.3 \\
Pyrodwarf & 1104.4 & 13.6 & 2.3 \\
MA & 927.3 & 13.0 & 2.6 \\
OHxF 333 & 856.1 & 10.9 & 3.4 \\
S 1 & 853.0 & 14.4 & 5.8 \\
BA 29 & 815.5 & 5.0 & 3.6 \\
\hline
\end{tabular}

statistically significant differences were confirmed between the individually tested rootstocks during the evaluation within the nursery (Fig. 4). Koběluš et al. (2007) reached the same conclusion in his work. Nevertheless, the problematic affinity of combinations with quince becomes evident when

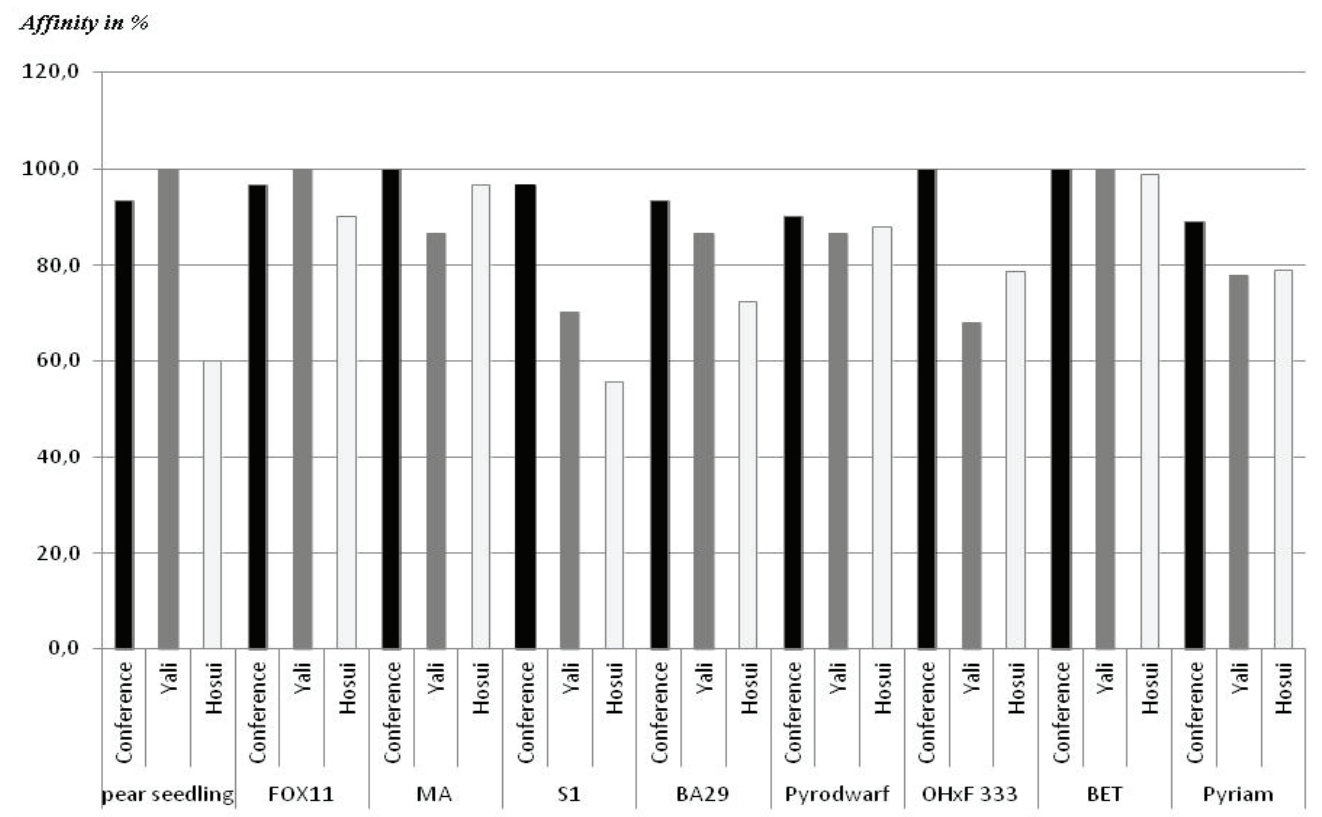

1: Comparison of average affinity value in tested rootstocks and cultivars (2009)

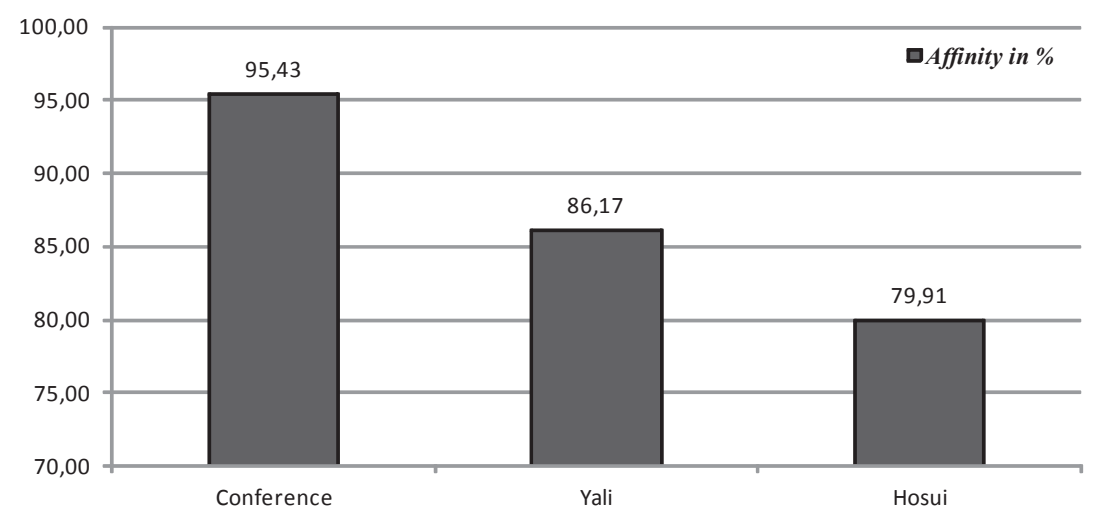

2: Comparison of average affinity value in tested cultivars (2009) 


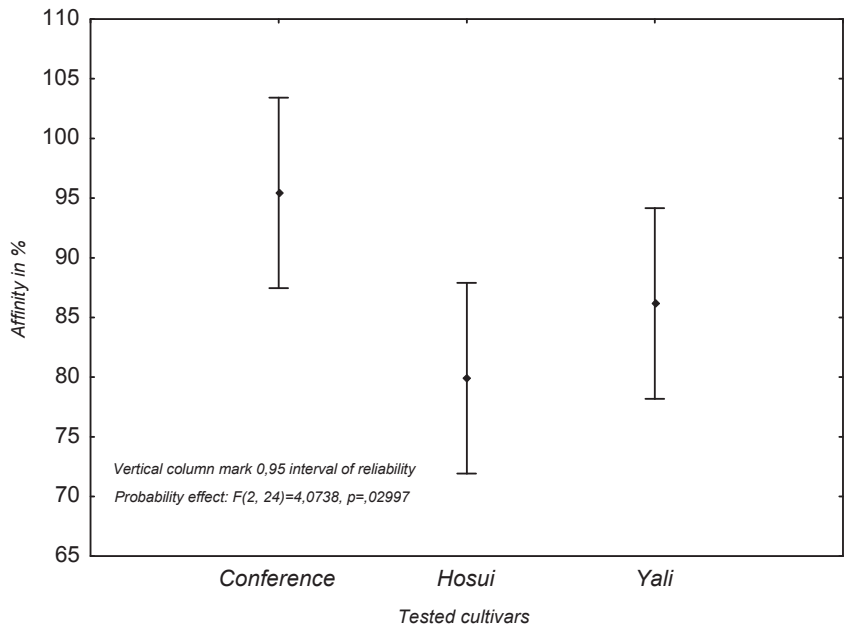

3: Confidence intervals for the average of $(\alpha=0.05)$ in the affinity between the tested varieties

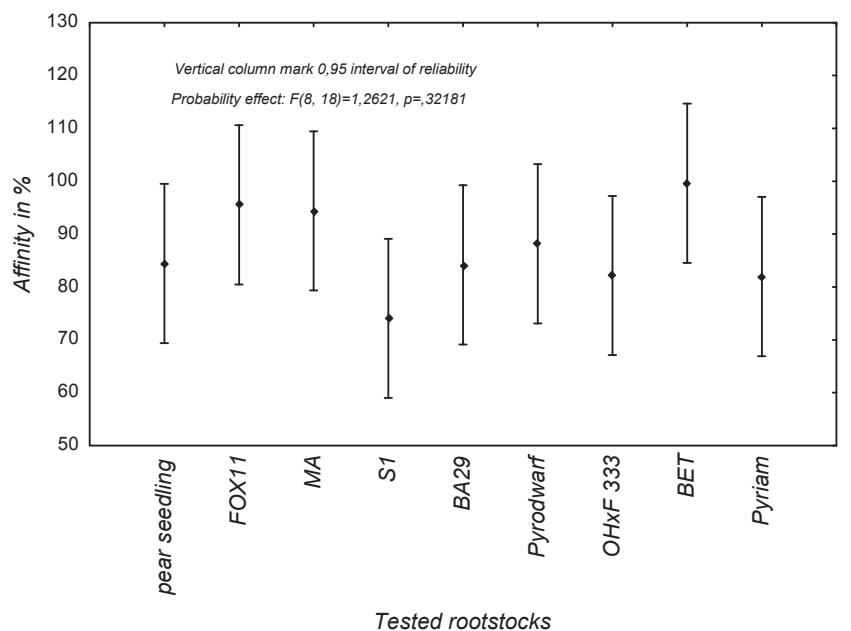

4: Confidence intervals for the average of $(\alpha=0.05)$ in the affinity between the tested rootstocks

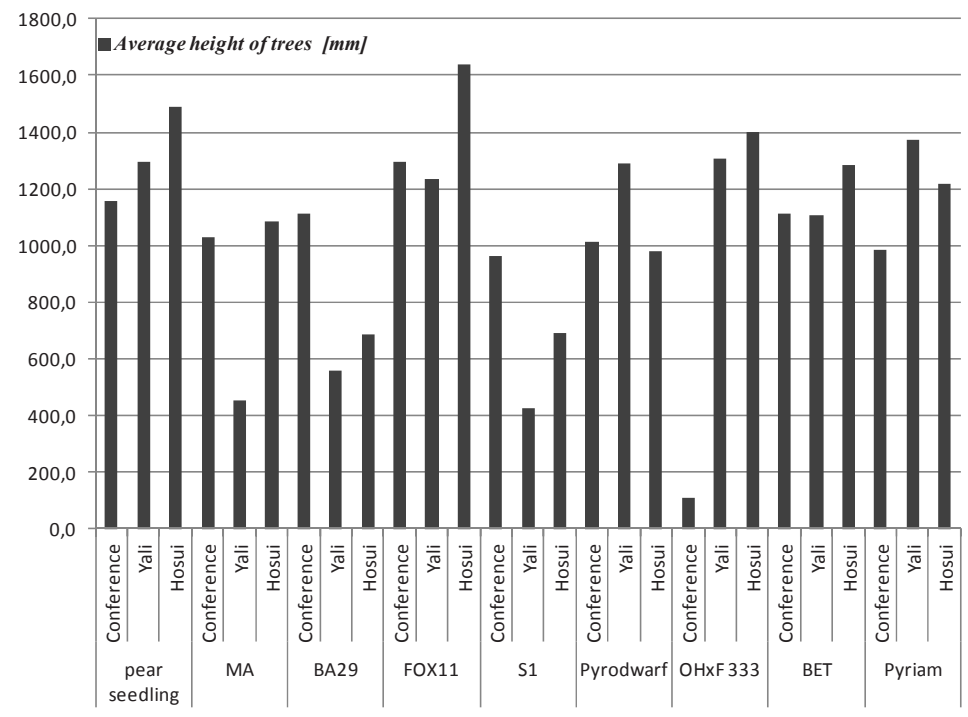

5: Average height of trees according to rootstocks (2008-2010) 
setting the orchard on a permanent site (data not published in this paper).

Another evaluated factor was the intensity of growth of the trees propagated by budding in the nursery. Based on the results, it is evident that the largest gains have been achieved with the 'FOX 11' rootstock $1388.8 \mathrm{~mm}$ on average. The second largest gains have been achieved with the two seed rootstocks of pear tree seedling for European and Asian pear trees ('BET') Table II. The longest gains have been seen in the 'FOX 11'/'Hosui' combination (1960 mm), whereas the shortest were identified in the 'OHxF 333'/'Conference' combination (23 mm). In the field of the growth intensity, the fact has been confirmed that the seed rootstocks significantly support the growth capacity. To compare the pear tree rootstocks with the quince rootstocks, the value of gains on the pear tree rootstocks is $1182.9 \mathrm{~mm}$, whereas with the quince it is $778.7 \mathrm{~mm}$. Therefore, the growth intensity on the quince rootstocks in the experiment has reached $65.8 \%$ of that on the pear tree rootstocks. On the other hand, the growth intensity of the trees propagated by budding in the 'Conference' variety on the quince rootstocks was by $8.8 \%$ higher. Generally speaking, the lowest gains have been recorded with the 'Yali' variety on the quince (46.2\% of the 'Conference' growth on the quince). Mutual combinations of rootstocks and varieties are depicted in Fig. 5. The statistical method of two-factor analysis of variance confirmed the highly significant differences in the length of gains among the varieties as well as among the rootstocks (Fig. 8).

Another growth factor evaluated was the thickness of the rootstock root crown. Fig. 6 shows the values of thickness of the root crown in mutual combinations of rootstock/variety. The results clearly state that one of the thickest growing rootstock is the 'BET' (P. pyrifolia) seedling with an average root crown thickness of $15.8 \mathrm{~mm}$. The second place is occupied by the 'FOX 11' rootstock $(15.1 \mathrm{~mm})$ and the pear tree seedling (14.8 $\mathrm{mm})$. Generally speaking, the results correspond to those of experiments with similar focus. An interesting result was the discovery that the smallest thickening of the root crown has always appeared in combination of quince and the 'Yali' variety. Another interesting outcome is the values of the vegetatively propagated rootstock 'FOX 11', which make it one of the most exuberant rootstocks. Similar results were published by Massai et al. (2008), who describes the pear tree seedling clone 'Kirschensaller' as the most exuberantly growing rootstock, followed by the rootstock from the OHxF group ('Farold 282') and 'FOX 11'. The vegetatively propagated rootstocks are typically required to weaken the growth. This cannot be demonstrated with 'FOX 11'. The 'Pyriam' rootstock only achieved average values of growth. Whereas that Iglesias, (2011b) in similar experiment mentions 'Pyriam' as the most exuberantly growing rootstocks. Very interesting result is the crown thickness of $14.4 \mathrm{~mm}$ in the 'Sl' rootstock, i.e. thicker than 'MA' and 'BA29', whereas the experiment by Lewko et al. (2007) identified that the quince root crown thickness is $13.7 \mathrm{~mm}$ on average, i.e. always lower than with quince 'MA'. The lowest values of thickness were achieved with the 'BA29' rootstock (5.0 mm only). When comparing the thickness of the root crown between the group of pear tree and the quince rootstocks group, the average values were $14.0 \mathrm{~mm}$ in the pear tree rootstocks and $9.3 \mathrm{~mm}$ in the quince rootstocks. The difference in the thickening intensity of both the groups is up to $33.6 \%$. The statistical method of two-factor analysis of variance confirmed the highly significant differences in the

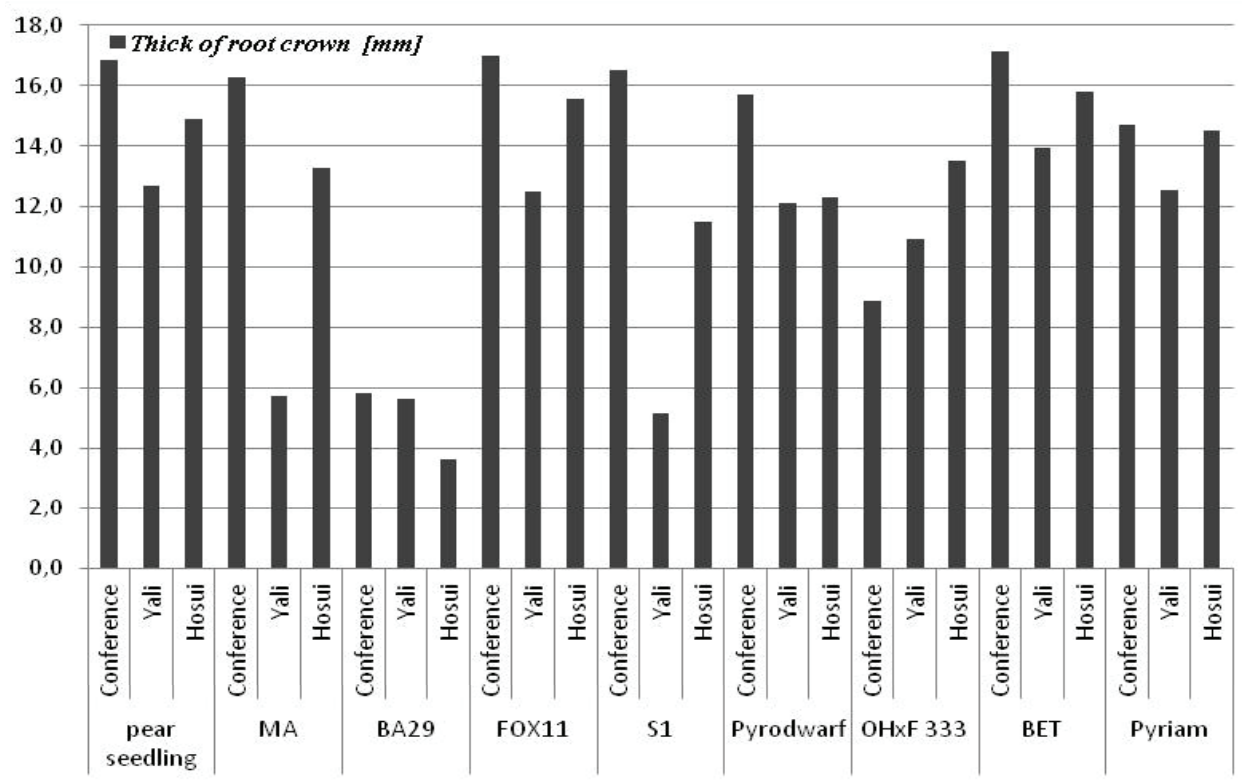

6: Average thick of root crown according to rootstocks (2008-2010) 
thickness of the root crown among the varieties as well as among the rootstocks (Fig. 9).

The last evaluated sign is the intensity of root suckering. For results of influence of the rootstock/ variety interactions on the suckering, see Fig. 7. The highest values of suckering were achieved by the seed rootstock 'BET', an average total of 6.2 suckers/tree propagated by budding. A relatively high suckering was also exhibited by the "pear seedling' rootstock (5.6 suckers/tree propagated by budding). Low figures of root suckering were also identified with the quince 'MA' and the 'Pyrodwarf' rootstocks (2.6 and 2.3 suckers/tree propagated by budding respectively). Extremely high figures were reached by the quince rootstock 'S1' (5.8 suckers), which might have been caused by very poor affinity and formation of ambient growth around the bud slit. When comparing the pear tree rootstocks and the group of quince rootstocks the average values were 4.4 pieces in the pear tree rootstocks and 4.0 pieces in the quince rootstocks. The difference in root suckering reaches $9.1 \%$ in favour of the quince rootstocks. The statistical method of two-factor analysis of variance confirmed the highly significant differences in the formation of root suckers among the varieties as well as among the rootstocks (Fig. 10).

\section{CONCLUSION}

Based on the statistical analyses, it was demonstrated that the tested rootstocks and varieties themselves have statistically significant influence

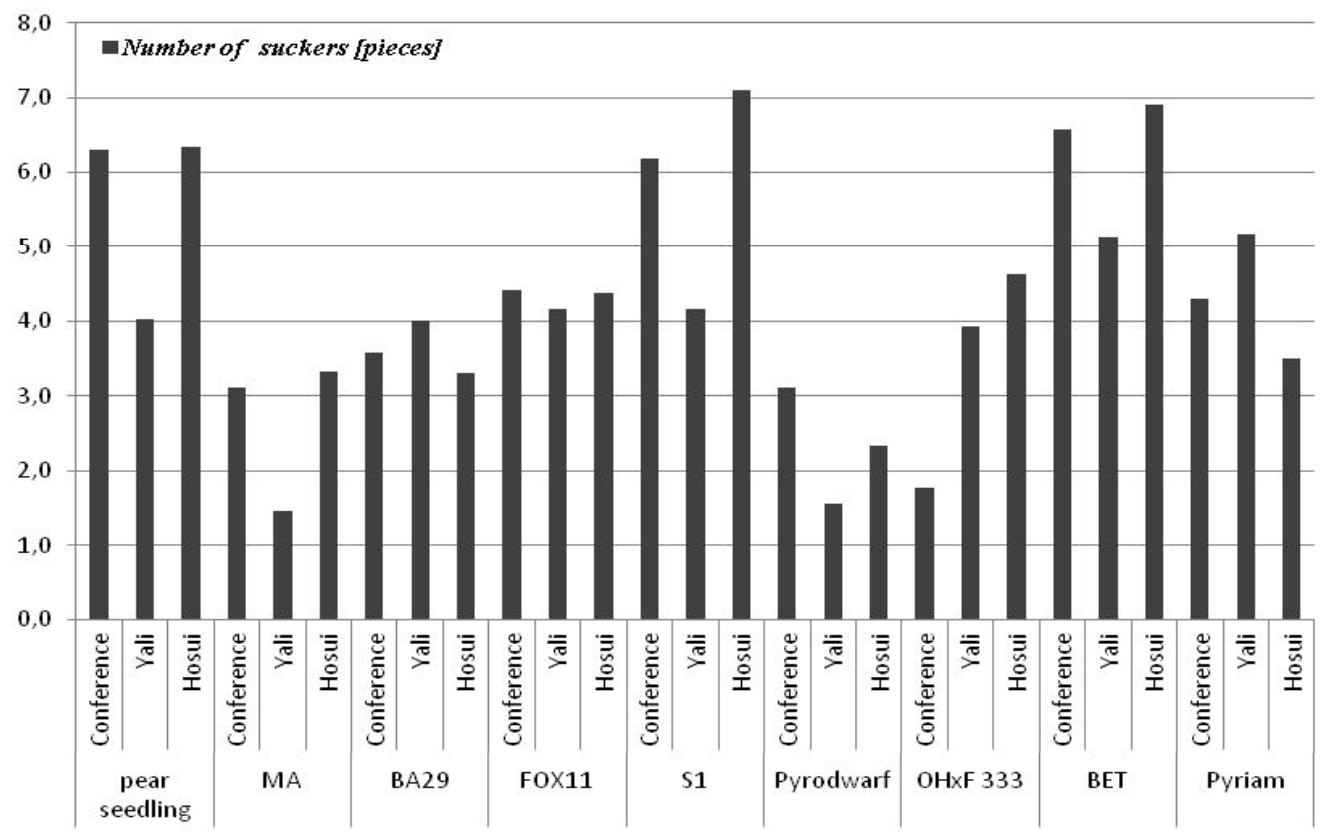

7: Average number of suckers according to rootstocks (2008-2010)

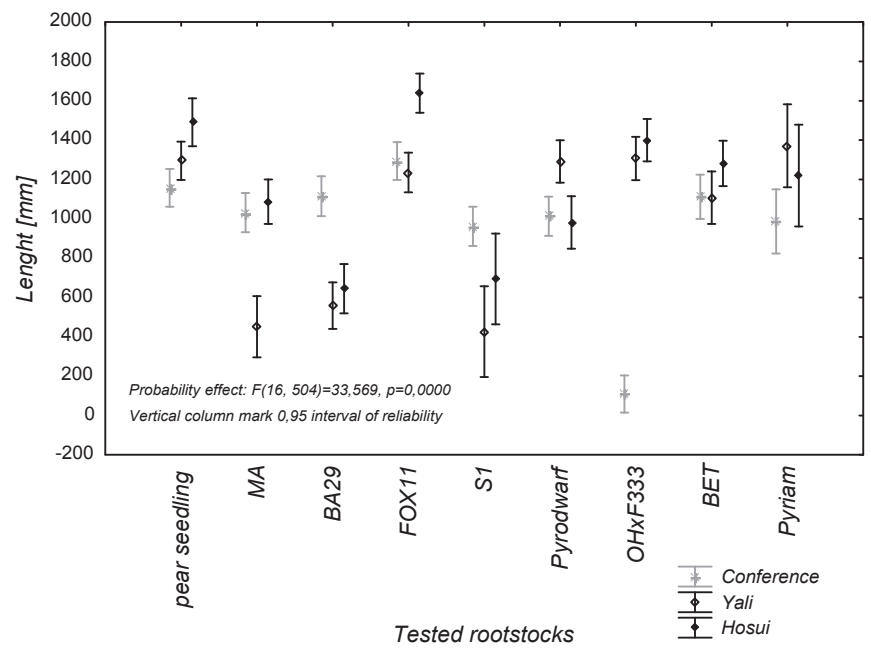

8: Confidence intervals for the average $(\alpha=0.05)$ in the length of trees propagated by budding between the tested rootstocks 


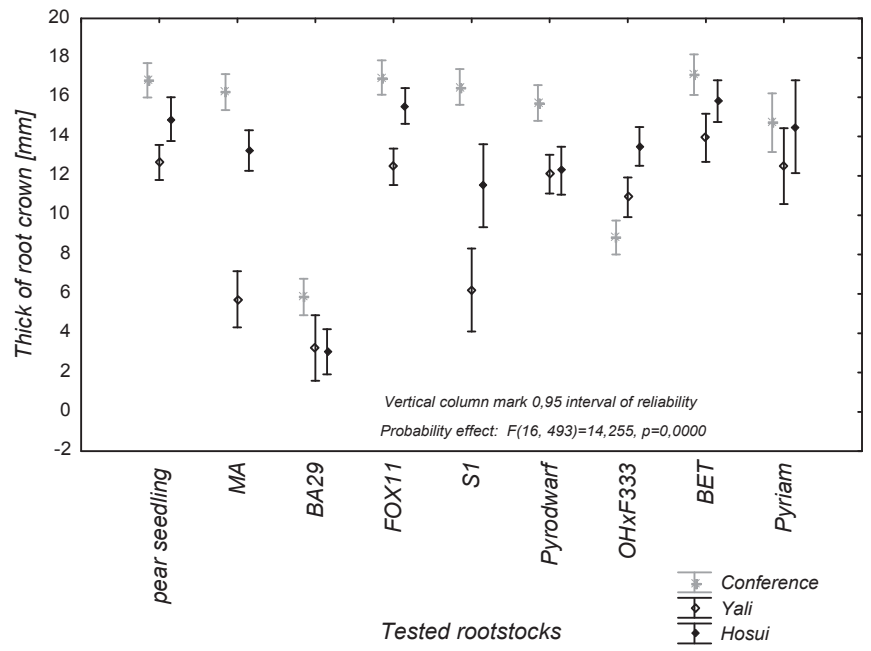

9: Confidence intervals for the average of $(\alpha=0.05)$ in the thickness of the root crown between the tested rootstocks

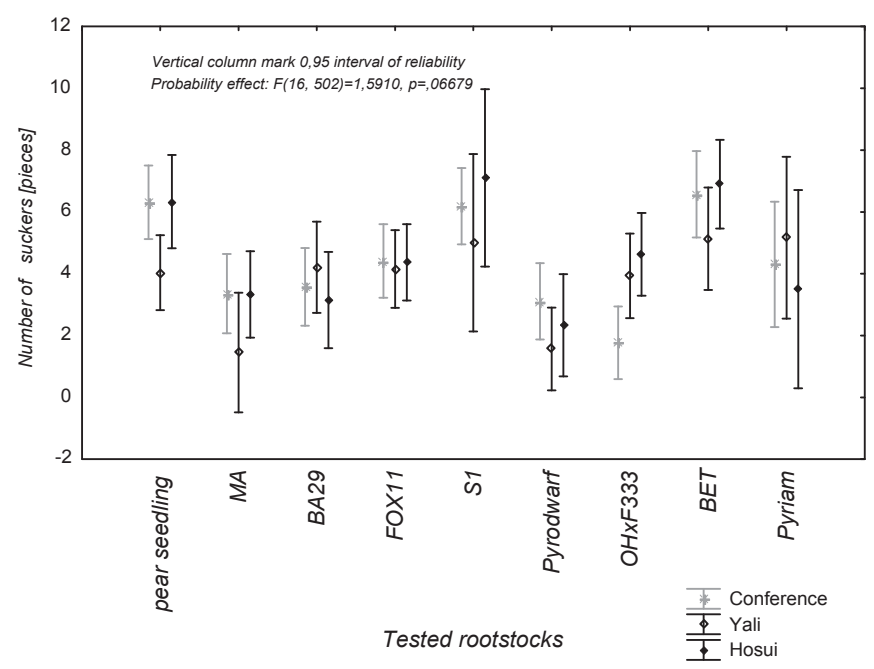

10: Confidence intervals for the average of $(\alpha=0.05)$ in the formation of suckers between the tested rootstocks

on the formation of trees in the nursery or on the signs and traits observed. The primary success sign of the nursery production of the grafted trees is the excellent affinity of the rootstocks and the scions. The growth character has influence not only on the quality of the cultivar, but also on the behaviour of the tree on its permanent site (e.g. fruitfulness).

The experiment identified statistically significant differences in the affinity of varieties with the best results achieved by the 'Conference' variety (95.4\% of successful affinity on average) in combination with the 'OHxF 333' and 'BET' rootstocks achieving the affinity at $100 \%$. In the quince rootstocks, the highest affinity was achieved with the 'MA' rootstock (100\%). Assessment of the Asian varieties affinity, as the specific target of the experiment, suggests that they encounter the same problems of affinity in the quince rootstocks as the European varieties. Although the 'Yali' variety on the pear tree seedling, 'FOX 11' and 'BET' reached the affinity of up to
$100 \%$, the best results on the quince rootstocks ('MA' and 'BA29') were only $86.6 \%$. The 'Hosui' variety reached a high affinity only in combination with the 'MA' rootstock (96.6\%), whereas in all other cases the affinity was lower. The lowest affinity in general was achieved in combination of Asian varieties and 'Sl' quince. The signs of the so-called secondary disaffinity are expected to appear in further years of evaluation; these signs include poor or no affinity, decay of trees on the quince rootstock planted on a permanent site.

The evaluated growth traits of rootstocks and varieties exhibited highly statistically significant differences. It can be stated, that the rootstocks significantly influence the intensity even in the Asian varieties; the results also demonstrate some evident differences even in the very Asian varieties. The 'Hosui' variety has been identified as the most exuberantly growing, the difference between the average length of its gains and those of the control 
variety 'Conference', which also proved to be the least growing according to the results, was up to $22.2 \%$. Similarly, the difference in the length of the most growing rootstock 'FOX 11' and the least growing 'BA29' was as significant as 41.3\%. Such a difference is of economic importance, with respect to the overall vitality of the cultivar. These results also imply that the 'FOX 1l' rootstock would not be suitable for intensive orchards. The thickness of the root crown is a direct sign, which can be measured after budding the scion on the rootstock and thereby identifying the intensity of growth of the very rootstock. Practical difference between the thickness of the root crown at the least and the most growing rootstocks reached $10 \mathrm{~mm}$; such a difference was evaluated as highly statistically significant and important for the quality of the nursery-bred cultivars. The highest values of thickening were achieved by the seed pear rootstock and 'FOX 11', which corresponds with their influence on the length of the trees propagated by budding. Minimum thickening was exhibited by the quince rootstock 'BA 29'. Formation of root suckers is a negative property of the rootstocks, not only for the nursery gardener but also for the fruit-grower. With respect to this character, the best results were achieved by the 'Pyrodwarf' rootstock from the invitro culture, which shows practically no signs of root suckering. The disadvantage of this rootstock, especially of the in-vitro culture, is the weaker branching of the root system. By contrast, the most root suckers were formed at the 'BET' rootstock and the pear tree seedling, which corresponds with the common experience with these rootstocks. Formation of strong suckers at the 'Sl' rootstock is quite untypical.

To draw some practical conclusions from the results of the experiment to recommend suitable rootstocks for the Asian varieties, the 'Pyrodwarf' rootstock would be the one to recommend. For the 'Pyriam' and 'OHxF 333' rootstocks, it is still necessary to assess their affinity with the Asian varieties to a larger extent.

\section{SUMMARY}

Evaluation of nursery traits in the selected rootstock/variety combinations in Asian pear trees has established as its objective to explain the issues concerning the growing of this most productive variety group of pear trees in the local conditions of the Czech Republic. Owing to the situation in the pear production and rather unfavourable stagnation of the breeding areas for pears in the Czech Republic, it is of current importance to provide the fruit growers a suitable stimulus to focus on. The present experiment deals with the first part of the project, aimed at examination and verification of the selected nursery traits. The experiment covering more than 800 trees propagated by budding evaluated the affinity of varieties with the rootstocks, growth of the trees propagated by budding, growth of the rootstocks and formation of the suckers on the rootstocks. The highest values of affinity identified during the evaluation in the nursery were achieved with the following rootstocks: 'BET' (96.6\%), 'FOX 11' (95.5\%), and 'MA' (94.4\%). Lower affinity in general was experienced in the quince rootstocks. Based on the experiment results, the signs of the so-called secondary disaffinity are expected to appear in further years of evaluation; these signs include poor or no affinity, decay of trees on the quince rootstock planted on a permanent site. 'Hosui' was identified as the variety with the greatest growing capacity, with an average gain of $1238.2 \mathrm{~mm}$, followed by the varieties 'Yali' (1092.9 mm) and 'Conference' $(963.4 \mathrm{~mm})$. The most supported variety growth was exhibited by the 'FOX 1l' rootstock, with an average gain of the trees propagated by budding of $1388.8 \mathrm{~mm}$, followed by the pear tree seedling $(1288.8 \mathrm{~mm})$ and 'BET' rootstock $(1171.3 \mathrm{~mm})$. The growth intensity of the rootstocks was mostly demonstrated in the thickness of the root crown of the 'BET' (P. betulifolia) rootstock, namely $15.8 \mathrm{~mm}$. The rootstock that exhibited the strongest root suckering was also 'BET' with 6.2 suckers per rootstock. The identified differences between the varieties and rootstocks were confirmed as statistically significant or even highly statistically significant.

Acknowledgement

This work was funded by the project No. NAZV/KUS QJ1210036 by the Ministry of Agriculture.

\section{REFERENCES}

FAO, 2010, dostupné z: http://faostat.fao.org/ site/567/default.aspx\#ancor, [20.8.2012].

BELL, R. L., 2003: Resistance to pear psylla nymphal feeding of germplasm from central europe. Acta Hort. (ISHS) 622, pp. 343-345, ISSN 0567-7572.

BOKSZCZANIN, K. L., PRZYBYLA, A. A., SCHOLLENBERGER, M., GOZDOWSKI, D., MADRY, W., ODZIEMKOWSKI, S., 2012:
Inheritance of fire blight resistance in Asian Pyrus species. Open Journal of Genetics, Vol. 2, No. 2, pp. 109-120, ISSN 2162-4453.

BREWER, L. R. and PALMER, J. W., 201l: Global pear breeding programmes: goals, trends and progress for new cultivars and new rootstocks. Acta Hort. (ISHS) 909, pp. 105-119, ISSN 05677572. 
BUCHTOVÁ, I., 201l: Situační a výhledová zpráva ovoce, MZe Praha, pp. 82, ISBN 978-80-7084-9859.

GEMMA, H., 2008: Recent situation of pear industry in Asia. Acta Hort. (ISHS) 800, pp. 71-78, ISSN 0567-7572.

IGLESIAS, I. and BATLLE, I., 201la: Agronomical performance and fruit quality of 'Conference' on some Cydonia and Pyrus rootstocks. Acta Hort. (ISHS) 909, pp. 195-200, ISSN 0567-7572.

IGLESIAS, I. and ASÍN, L., 2011b: Agronomical performance and fruit quality of 'Conference' pear grafted on clonal quince and pear rootstocks. Acta Hort. (ISHS) 903, pp. 439-442, ISSN 0567-7572.

JACOB, H. B., 1998: PYRODWARF, a new clonal rootstock for high density pear orchards. Acta Hort. (ISHS) 475, pp. 169-178, ISSN 0567-7572.

JUN, W., HONGSHENG, G., 2002: The production of Asian pears in China. Acta Hort. (ISHS) 587, pp. 71-80, ISBN 978-90-66057-66-1.

KALÁŠEK, J., JERMATOVÁ, E., RICHTER, M., SCHUBERT, V., 1980: Metodiky státních odrůdových zkoušek - ovocné plodiny, ÚKZÚZ Praha, tisk Tomos, pp. 186.

KOBĚLUS, V., ŘEZNÍČEK, V. and SALAŠ, P., 2007: Cydonia mill. as a pear rootstock and its effect on the young plant quality of pears in the nursery. Acta Hort. (ISHS) 732, pp. 233-237, ISSN 05677572

KVIKLYS, D. and KVIKLIENE, N., 2008: Investigations on pear rootstocks at north European climatic conditions. Acta Hort. (ISHS) 800, pp. 671-674, ISSN 0567-7572.

LEWKO, J., ŚCIBISZ, K. and SADOWSKI, A., 2007: Performance of two pear cultivars on six different rootstocks in the nursery. Acta Hort. (ISHS) 732, pp. 227-231, ISSN 0567-7572.

LORETI, F., MORINI, S., 1977: Propagation of Pyrus betulaefolia Bunge by stem cutting. Acta Hort. (ISHS) 69, pp. 123-128, ISSN 0567-7572.

LUO, Z. R., ZHANG, Q. L., 2002: The genetic resources and their utilization of Pyrus pyrifolia in China. Acta Hort. (ISHS), 587, pp. 201-205, ISBN 978-90-66057-66-1.

MARANGONI, B., RIVALTA, L. 1995: Portinesti fruttiferi.Suplemento a L'Informatore Agrario, 32, pp. 33-35.
MASSAI, R., LORETI, F. and FEI, C., 2008: Growth and yield of 'Conference' pears grafted on quince and pear rootstocks. Acta Hort. (ISHS) 800, pp. 617-624, ISSN 0567-7572.

MATSUMOTO, K., TAMURA, F., CHUN, J., ZHANG, C., TANABE, K., 2008: Influences of $\mathrm{NaCl}$ on the growth, photosynthesis, ion and water relations in rootstocks of Japanese pear. Acta Hort. (ISHS) 772, pp. 231-235 2008, ISSN 0567-7572.

MITCHAM, E. J., ELKINS, R., B., 2007: Pear production and handling manual. University of Carolina Agriculture and Natural Resources Publication 3483, ISBN 978-1-879906-65-5.

MUSACCHI, S., 2006: Recenti innovazioni dell'impiantistica e della tecnica colturale del pero. Italus Hortus 13 (6), pp. 24-31.

NCGR, 2012, Corvallis Pyrus Catalog, dostupné z: http://www.ars-grin.gov/cor/catalogs/pyrasian. html, [7. 10.2012].

NEE, C. C., TSA, C. H., ANSTINE, D. D., 2002: Asian pear germplasm - future trends and current research in the industry. Acta Hort. (ISHS), 587, pp. 61-69, ISBN 978-90-66057-66-1.

NEČAS, T., KRŠKA, B., 2011: Použití bylinných řízků při množení některých podnoží ovocných dřevin. Zahradnictví. sv. X, č. 7, pp. 14-17, ISSN 1213-7596.

NEČAS, T., 2010: Pěstujeme hrušně a kdouloně. 1. vyd. Praha: Grada Publishing, pp. 99, ISBN 97880-247-2500-0.

QUARTIERI, M., MARANGONI, B., SCHIAVON, L., TAGLIAVINI, M., BASSI, D., PREVIATI, A., GIANNINI, M., 2011: Evaluation of pear rootstock selections. Acta Hort. (ISHS) 909, pp. 153-159, ISSN 0567-7572.

SEEMÜLLER, E., LORENZ, K.H. and LAUER, U., 1998: Pear decline resistance in Pyrus communis rootstocks and progenies of wild and ornamental Pyrus taxa. Acta Hort. (ISHS) 472, pp. 681-692, ISSN 0567-7572.

SIMARD, M. H. and MICHELESI, J. C., 2002: 'PYRIAM' a new pear rootstock. Acta Hort. (ISHS) 596, pp. 351-355, ISSN 0567-7572.

ÚKZÚZ, 2012: http://nou.ukzuz.cz/ido/ (20. 8. 2012).

VACHŮN,Z., 2001: Ovocnictví - podnože ovocných dřevin. Brno: Mendelova zemědělská a lesnická univerzita v Brně, pp. 67, ISBN 80-7157-217-9. 